\title{
Re-examination of the concept of innovativeness in the context of the adolescent segment: Development of a measurement scale
}

Received (in revised form): 24th February, 2004

\section{Jonathan B. Hartman}

is a doctoral candidate at the University of Arizona (USA) Department of Retailing and Consumer Sciences. He earned his MBA from the American Graduate School of International Management before spending 20 years in international business and advertising practice. He has published in the conference proceedings of the American Marketing Association.

\section{Kenneth C. Gehrt}

is Professor of Marketing at San Jose State University (USA). He earned his PhD in Marketing at the University of Kentucky. His more than 30 refereed journal articles appear in publications such as International Review of Marketing, Journal of Retailing, Psychology and Marketing, Journal of Global Marketing and Journal of Marketing Education.

\section{Kittichai Watchravesringkan}

is a doctoral student in the Department of Retailing and Consumer Sciences at the University of Arizona (USA). His work has been published in Clothing and Textiles Research Journal, in the book 'Diversity in Advertising', and in numerous conference proceedings including the American Marketing Association, the Academy of Marketing Science, and Advertising and Consumer Psychology.

Jonathan B. Hartman PO Box 210033, University of Arizona, Tucson, AZ 85721-0033, USA.

Tel: +1 520621 1295; e-mail:

jhartman@ag.arizona.edu

\begin{abstract}
As the role of young consumers in the consumption of technology-oriented products grows, so does the need to fully understand their contemplation, use and adoption of those products. Existing innovativeness scales have tended to measure consumers' desire to be first to buy new products. Bias related to this adoptive-oriented conceptualisation overlooks important aspects of innovativeness among younger consumer segments. Utilising an empirically untested conceptualisation of innovativeness that includes an adoptive-innovative dimension as well as a use-innovative dimension and a vicarious-innovative dimension, this study provides a more fully elaborated measurement of innovativeness that is particularly appropriate for measuring innovativeness among younger consumer segments. The results begin to provide a better understanding of innovativeness for segments whose innovative proclivities may be overlooked by extant scales.
\end{abstract}

\section{INTRODUCTION}

This research re-examines the concept of innovativeness by developing a scale that attempts to measure more fully the dimensionality of innovativeness. Extant scales tend to focus on the adoptive dimension of innovativeness. ${ }^{1} \mathrm{~A}$ conceptualisation posited by Hirschman ${ }^{2}$ includes adoptive innovativeness as well as use innovativeness and vicarious innovativeness. This study operationalises the three-dimensional conceptualisation 
in the context of a population for which unidimensional, adoptive-oriented scales may prove inadequate - adolescent consumers.

Researchers and practitioners are paying greater attention to adolescents because of their enormous buying power. Adolescents are growing up in a world in which changing family lifestyles demand that they be increasingly sophisticated and responsible consumers. ${ }^{3}$ Spending by American adolescents, for instance, is estimated to exceed US $\$ 150$ bn annually. When family spending that is influenced by adolescents is included, the estimates are substantially higher. ${ }^{4}$ The flurry of digital technology further confers on adolescents, who often exhibit a natural adroitness with such products, increasing influence on their families' high-technology product purchases. ${ }^{5}$ Although adolescent consumers have the requisite money and knowledge, however, adult family members tend to execute the major family consumption decisions. Thus, there is a need to measure innovativeness in a manner that transcends acquisition. For situations in which it is important to identify the most innovative individuals among younger segments such as introductions of new consumer electronic products, this provides incremental knowledge to what already exists.

Differing conceptualisations of innovativeness include a generalised personality trait ${ }^{6,7}$ that predisposes consumers to purchase new products ${ }^{8}$ and a socially influenced aspect of one's personal behaviour. ${ }^{9}$ Innovativeness is defined for this study as activities involving product contemplation, adoption and use. ${ }^{10,11}$ In her seminal article, Hirschman ${ }^{12}$ conceptualised innovativeness as a tripartite phenomenon. First, through learning and imagination, consumers acquire increasing knowledge about products (vicarious innovativeness). Secondly, consumers acquire or adopt products (adoptive innovativeness). Thirdly, consumers tinker with and solve novel consumption problems with products they have on hand (use innovativeness).

The innovativeness construct has been useful in past research for measuring consumers' adoption behaviour of technologically-advanced consumer products. There are several valid and reliable extant scales. For the most part, these scales operationalise innovativeness by inquiring about the number of innovative products recently purchased. These scales may not be valid for use with adolescents due to the bias of the scales, attributable to their focus on product acquisition. Several consumer scales have been shown to be insensitive to particular groups. ${ }^{13}$ This problem may be especially evident with the study of innovativeness as Rogers ${ }^{14}$ suggested some time ago. As a result of the acquisition orientation of innovativeness scales, the affluent adult male has emerged as the innovative consumer. ${ }^{15}$ Innovativeness scales, for instance, have been shown to be biased against women due to the acquisition-oriented nature of the existing scales. ${ }^{16}$ It is suggested that innovativeness scales may be biased towards other segments due to this acquisition predilection. ${ }^{17,18}$

\section{PURPOSE OF STUDY}

Because of the potential biases of existing scales, the purpose of this study is to develop a scale that more fully measures the phenomenology of innovativeness. This will be done within the context of adolescent consumers. Hirschman's ${ }^{19}$ three-dimensional notion of innovativeness will guide the research. The innovativeness dimensions of vicarious, use and adoptive innovation are discussed further in the literature 
review. By understanding the full dimensionality of innovativeness, a more complete understanding of innovativeness will result and efforts to identify and penetrate consumer segments successfully will follow. This will be particularly the case for segments whose innovativeness is inadequately measured by extant scales such as the adolescent segment.

\section{LITERATURE REVIEW}

\section{Conceptualisations of innovativeness}

According to one widely embraced conceptualisation, innovativeness is the behaviour of consumers purchasing new products and processes. ${ }^{20}$ This conceptualisation may be responsible for the acquisition orientation of innovativeness research and for the belief that the affluent young male is the typical innovative consumer. Several researchers have viewed innovativeness as a generalised personality trait ${ }^{21,22}$ and have suggested that consumers may be born with varying degrees of innovativeness. ${ }^{23,24}$ The effort to draw distinctions between the behaviour of adoption and the psychological trait of innovativeness $^{25,26}$ led Subramanian and Mittelstaedt ${ }^{27}$ to suggest the possibility of a person possessing a high degree of innovativeness while not being an early adopter. Venkatraman ${ }^{28}$ agreed that a prevalent problem with past innovativeness research was that innovators were so designated because of their new product adoption behaviour. It is argued that consumer innovativeness is really the desire for new experiences and more recent research has viewed innovativeness as a latent underlying preference for new and different consumption experiences rather than acquisitiveness. ${ }^{29}$ For the purpose of the present study, innovativeness will be conceptualised in this manner.

\section{Macro view: Diffusion of innovations in the population}

Diffusion of innovation theory suggests that innovations (new products and ideas) are adopted throughout society over time. $^{30}$ The theory has evolved over decades in many fields of research such as anthropology, sociology, consumer behaviour and marketing. ${ }^{31}$ Dimensions of diffusion include rate, pattern and potential population penetration. ${ }^{32}$ Robertson $^{33}$ classified three types of innovations: continuous, dynamically continuous and discontinuous. A continuous innovation is a modification of an existing product representing a small improvement (eg a flavoured tea bag). A dynamically continuous innovation represents a greater departure from prior products, where disruption in the user's established pattern takes place (eg electric automobiles). Discontinuous innovation necessitates fundamental alteration of established patterns. ${ }^{34,35}$ Examples include the first televisions, automobiles and birth control pills. Innovative products can be symbolic, communicating social meaning such as a new fashion, or technological, involving a functional advancement such as jets over propeller planes or computers versus typewriters and adding machines. ${ }^{36,37}$ The position occupied by the product on the innovation continuum indicates the learning requirements of the innovation which in turn directly affect the rate with which the innovation is embraced by society. Adopters in the overall population are classified into categories including innovators, early adopters, early majority, late majority and laggards. ${ }^{38}$

\section{Micro view: Adoption by the individual}

The present study focuses on the micro view of personal innovativeness (ie an individual's product contemplation, adoption and use). In the micro view, 
adoption is defined as an individual's decision to become a regular user of a product. ${ }^{39}$ Rogers ${ }^{40}$ speculated that five characteristics affect adoption by an individual:

1) relative advantage, or the perception that the product is better than what it replaced;

2) compatibility, which is conformity of the product to the individual's experiences, needs, values;

3) complexity, meaning the perception of difficulty inherent in product use;

4) trialability, or the ease with which the product can be used without undue user commitment;

5) communicability/observability, or the ability for the user to show the product in use.

Individuals pass through five steps in order to adopt or reject a product:

1) obtain knowledge (awareness);

2) form an attitude towards (interest);

3) decide to adopt or reject (evaluation);

4) implement (trial);

5) confirm the decision by using the product. $^{41}$

Inherent in these conceptualisations is a three-part phenomenon of product contemplation, acquisition and use. It is perhaps for this reason that Hirschman ${ }^{42}$ proposed that a three-dimensional conceptualisation of innovativeness would better represent this process: adoptive, vicarious and use innovativeness. Based on Hirschman's three-dimensional conceptualisation, adoptive innovativeness is defined in the literature as acquisition of a product and is the aspect of innovativeness that has dominated the past research. Rogers and Shoemaker ${ }^{43}$ described innovativeness as the degree to which an individual is relatively earlier in adopting an innovation than other members of his social system'. Midgley and Dowling ${ }^{44}$ suggested that this is a measure of behaviour, not an 'expression of an individual's cognitive construction'. ${ }^{45}$ Innovativeness has essentially been measured as purchasing behaviour in the literature, focusing on acquisition of high-technology products. $^{46}$

Vicarious innovativeness is described as an active search for information about new or unfamiliar products ${ }^{47}$ or adopting a product concept in the imagination without actually acquiring the product. ${ }^{48}$ Vicarious innovativeness (vicarious exploratory behaviour) differs from exploratory purchase behaviour in that purchases are not made. ${ }^{49}$ Hirschman $^{50}$ and Raju ${ }^{51}$ suggest that vicarious innovativeness consists of information gathering for decision making about future purchases. The consumer can collect and retain information about new products that will be available for future decision making without the inherent risk of buying the product. Further, the consumer can, through vicarious experience, increase consumption knowledge. No vicarious innovativeness scales exist to date. Hirschman suggests that this construct be operationalised by asking subjects to report the new products and consumption situations learned about recently but not actually experienced or adopted.

Use innovativeness refers to variety seeking in product use; the consumer's actions are innovative when using an extant product to resolve a new consumption obstacle. Hirschman's ${ }^{52}$ conceptualisation suggested that use innovation relates to using a product in a manner not intended by the seller, using the product in a multitude of ways, or tinkering with a product. These levels of use innovativeness 
suggest that this construct describes product consumption behaviour in which existing products are reborn with new uses and tasks. An example of a new task for a product owned is using a weed whacker to strip peeling paint from an old rattan chair. This three-dimensional conceptualisation of innovativeness, vicarious exploration of products, adoption of products and use and consumption of products, is proposed by this research as necessary to capture the complete manifestation of innovativeness, particularly in adolescents who are not shown to be innovative using extant scales.

\section{The adolescent: A different consumer}

This study examines innovativeness among adolescents. Sigmund Freud ${ }^{53}$ and

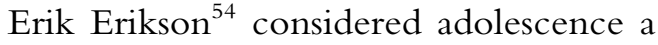
disruptive period with physiological changes, aggressive drives and social pressures that instigate role confusion. Erikson $^{55}$ speculated that the changes come so quickly that the adolescent does not recognise him/herself, perhaps causing heightened concern for appearance. It may, however, be the social pressures creating the feeling of inadequacy in the world and diminishing willingness to be different and innovative as they age. Schachtel ${ }^{56}$ suggested that as they mature, older adolescents and adults have increasing misgivings about deviating from the way their peers think; teachers, parents and peers may stifle creativity. This is not to say that adolescents have achieved cognitive maturity. Adolescents continue to be childlike in many ways. ${ }^{57}$ Bandura $^{58}$ proposed that adolescent judgment is faulty because judgment depends on experience the adolescent has yet to acquire. Adolescents are often occupied in playing and daydreaming and have active imaginations. This is important to their psychological wellbeing. ${ }^{59,60}$ Bandura $^{61}$ proposed that vicarious experiences are important to a child's development; a youth sees others doing a task, visualises completing the task and therefore is confident $\mathrm{s} /$ he can do it. Since daydreaming is a vicarious experience, and since vicarious learning is basic to this age group, it follows that young adolescents may be vicariously innovative. Another adult skill that has yet to emerge in early adolescence is the ability to generalise. ${ }^{62}$ Research has revealed that adolescents have less structured belief systems than adults and focus on the practical. ${ }^{63}$ Having neither the fully developed ability to generalise, nor a fully developed belief system to restrain them, adolescents may exhibit more use and vicarious innovativeness than adults would.

\section{METHODS}

\section{Selection of initial item pool}

Due to the dearth of prior innovativeness studies with adolescents, the researchers conducted eight focus group interviews with ten to 15-year-old middle-school children. The interviews took place in the students' classrooms in a mid-sized southwestern city and were videotaped and transcribed. The interviews were critical for 1) selecting items that are usable from existing scales; 2) determining how existing items could be adapted for the age group; 3) generating original items for a questionnaire. A total of 50 items resulted.

A pretest with approximately 60 middle-school students (50 per cent males, mean age of 13) was conducted, resulting in the elimination of 15 items that were unclear or repetitive and modification of several reverse coded items. These were reworded to be consistent with the other items for the 
clarity needed by the younger subjects in particular. ${ }^{64}$ The objective was to select the smallest possible number of items that could assess the three a priori constructs so as to reduce the time to complete the questionnaire, very important considering the age and attention span of young subjects. Examples of items are as follows: adoptive innovativeness included an item, 'I usually buy high tech products before my friends do'. Use innovativeness included, 'When I take things apart I don't worry about being able to put them back together' and 'I save broken stuff because I might be able to use the parts for something else'. Vicarious innovativeness included, 'I imagine what things like travel, communication, and shopping will be like in the future' and 'There are some cool products that I don't have, but I know how to use'. Behavioural measures included items such as 'I use the computer for finding general information' and 'I use the internet to surf the web just for fun'. Response options were arranged in a Likert-type format, ranging from 1 = strongly disagree to $5=$ strongly agree.

\section{Item selection and data collection}

Questionnaires were distributed to 330 students in two middle schools in a mid-size southwestern city. The first was predominantly white, and middle to upper middle class $(n=155)$; the second one was predominantly Hispanic, and lower middle and working class $(n=154)$. The subjects were 42 per cent male and 58 per cent female; the mean age was 12.7 . The survey contained assent language on the first page. A total of 309 surveys were usable, a sufficient number for developing a scale of this size. ${ }^{65,66}$ The questionnaires were collected by the children's teachers.

\section{DATA ANALYSIS}

\section{Step 1: Identification of factors of innovativeness}

Three procedures were employed to assess the efficacy of the 35 remaining items for the three a priori scales. These included: 1) differential Cronbach's alpha reliability analysis on each of the three subscales and on the total scale; 2) individual factor analysis on each of the three subscales; 3) item total correlations on the total scale and item subtotal correlations on each of the three subscales. Multiple techniques were employed so that several criteria could be used for the selection of the final scale items used to create a model for testing. ${ }^{67,68}$ First, each a priori specified subscale was individually factor analysed. This procedure revealed a total of ten items for elimination (with loadings below 0.50) on the three subscales. The overall alpha and individual subscale alpha coefficients improved with each of the ten items that were eliminated. Internal consistencies of the scales were high. Alpha levels ranged from 0.66 to 0.80 on the subscales, and 0.86 on the total scale, satisfactory levels for a scale of this kind. ${ }^{69}$ Next, differential Cronbach's alpha analysis performed on each subscale revealed four additional items for elimination. Finally, item total and subtotal correlations were computed with summated scales employing multiple indicators to reduce measurement error. Item total and item subtotal correlations showed that the items of each a priori proposed subscale were highly correlated with their own subscale and the total scale and were not highly correlated with the other scales. ${ }^{70,71}$ Table 1 presents the subscales with factor loadings and subscale item total correlations.

Discrimination index ( $p$-value) psychometric analysis ${ }^{72}$ revealed that there was good variation on all items 
Table 1: Finalised items and factor loadings

\begin{tabular}{|c|c|c|c|c|}
\hline & & $\begin{array}{l}\text { Factor } \\
\text { loadings }\end{array}$ & $\begin{array}{l}\text { Item sub-total } \\
\text { correlation - } \\
\text { sub scale }\end{array}$ & $\begin{array}{l}\text { Item total } \\
\text { correlation - } \\
\text { total scale }\end{array}$ \\
\hline \multicolumn{5}{|c|}{ Vicarious: $(\alpha=0.80)$} \\
\hline & $\begin{array}{l}\text { When I hear about cool new products, I like to learn } \\
\text { about them. }\end{array}$ & 0.70 & 0.68 & 0.66 \\
\hline 2) & I wonder about what products will be like in the future. & 0.66 & 0.65 & 0.61 \\
\hline & I enjoy discovering new products and activities. & 0.65 & 0.61 & 0.59 \\
\hline 4) & $\begin{array}{l}\text { I imagine what things like travel, communication, and } \\
\text { shopping will be like in the future. }\end{array}$ & 0.63 & 0.63 & 0.57 \\
\hline 5) & $\begin{array}{l}\text { When I hear about cool new products that aren't out yet, } \\
\text { I want to learn about them. }\end{array}$ & 0.63 & 0.60 & 0.55 \\
\hline 6) & When I see new name brands, I want to try them out. & 0.56 & 0.57 & 0.52 \\
\hline 7) & I daydream about cool new products. & 0.56 & 0.59 & 0.52 \\
\hline 8) & $\begin{array}{l}\text { I spend a lot of time imagining what the future } \\
\text { would be like. }\end{array}$ & 0.55 & 0.57 & 0.47 \\
\hline 9) & $\begin{array}{l}\text { I shop around a lot for cool new stuff in stores just to } \\
\text { find out about the latest features or styles. }\end{array}$ & 0.55 & 0.56 & 0.49 \\
\hline 10) & $\begin{array}{l}\text { I think about how I would use different products, even } \\
\text { though I don't have them. }\end{array}$ & 0.54 & 0.56 & 0.48 \\
\hline \multicolumn{5}{|c|}{ Use: $(\alpha=0.71)$} \\
\hline 1) & $\begin{array}{l}\text { When I make something, I can usually make do with } \\
\text { stuff I've already got around. }\end{array}$ & 0.69 & 0.67 & 0.53 \\
\hline 2) & I like to try different things when using products. & 0.66 & 0.63 & 0.63 \\
\hline 3) & $\begin{array}{l}\text { I save broken stuff because I might be able to save the } \\
\text { parts for something else. }\end{array}$ & 0.64 & 0.67 & 0.48 \\
\hline 4) & I like products that you have to put together. & 0.64 & 0.65 & 0.46 \\
\hline 5) & $\begin{array}{l}\text { When I make things on my own, they usually turn } \\
\text { out really well. }\end{array}$ & 0.61 & 0.61 & 0.43 \\
\hline 6) & $\begin{array}{l}\text { I like to try different computer programs, even if I don't } \\
\text { need them now. }\end{array}$ & 0.61 & 0.60 & 0.60 \\
\hline \multicolumn{5}{|c|}{ Adoptive: $(\alpha=0.66)$} \\
\hline 1) & $\begin{array}{l}\text { I am usually one of the first of my friends to buy } \\
\text { products that involve new technology when they } \\
\text { come out. }\end{array}$ & 0.84 & 0.80 & 0.54 \\
\hline 2) & I usually buy high-tech products before my friends do. & 0.81 & 0.78 & 0.50 \\
\hline 3) & $\begin{array}{l}\text { I am usually one of the first of my friends to buy } \\
\text { 'new look' clothes when they come out. }\end{array}$ & 0.61 & 0.64 & 0.40 \\
\hline 4) & $\begin{array}{l}\text { I help my family with shopping for new technology } \\
\text { types of products. }\end{array}$ & 0.61 & 0.62 & 0.56 \\
\hline \multicolumn{5}{|c|}{ Total scale: $(\alpha=0.86)$} \\
\hline
\end{tabular}

with standard deviations ranging from 1.00 to 1.47 . The means and standard deviations were of a magnitude that indicated the respondents took the items seriously and that there was acceptable inter-subject variability. The three most difficult items to agree with related to being the first to buy new high-tech and high fashion products. This was expected, since these young people lack the discretionary income that would allow such purchases. The three easiest items to agree with were discovering new products and activities, imagining travel and shopping in the future, and trying new computer programs before they are specifically needed. This finding may be indicative of vicarious and use innovativeness in the subjects.

\section{Step 2: Confirmatory factor analysis test of the measurement model}

A hypothetical measurement model was developed with confirmatory factory analysis to assess the fit of the data to the 
Table 2: Measurement model LISREL estimates for confirmatory factor analysis

\begin{tabular}{|c|c|c|c|c|c|c|}
\hline Construct & Indicator & Path & $\begin{array}{l}\text { LISREL } \\
\text { estimates }\end{array}$ & $\begin{array}{l}\text { (Standardis } \\
\text { solution) }\end{array}$ & $\begin{array}{l}\text { sed } \\
\text { Residual }\end{array}$ & Variance \\
\hline \multirow[t]{2}{*}{$\xi_{1}$ Vicarious } & $\begin{array}{l}\mathrm{X}_{1} \text { Learn about cool new product } \\
\mathrm{X}_{2} \text { Contemplate future product types } \\
\mathrm{X}_{3} \text { Enjoy discovering products/activities } \\
\mathrm{X}_{4} \text { Imagine future travel and shopping } \\
\mathrm{X}_{5} \text { Learn about products before } \\
\text { being sold }\end{array}$ & $\begin{array}{l}\lambda_{11} \\
\lambda_{21} \\
\lambda_{31} \\
\lambda_{41} \\
\lambda_{51}\end{array}$ & $\begin{array}{l}0.91 \\
0.70 \\
0.60 \\
0.65 \\
0.68\end{array}$ & $\begin{array}{l}(0.76) \\
(0.55) \\
(0.60) \\
(0.52) \\
(0.60)\end{array}$ & $\begin{array}{l}\delta_{1} \\
\delta_{2} \\
\delta_{3} \\
\delta_{4} \\
\delta_{5}\end{array}$ & $\begin{array}{l}0.58 \\
0.31 \\
0.36 \\
0.27 \\
0.36\end{array}$ \\
\hline & $\begin{array}{l}\mathrm{X}_{6} \text { Try new name products } \\
\mathrm{X}_{7} \text { Daydream about new products } \\
\mathrm{X}_{8} \text { Imagining the future } \\
\mathrm{X}_{9} \text { Window shopping for cool stuff } \\
\mathrm{X}_{10} \text { Contemplate use of different } \\
\text { products }\end{array}$ & $\begin{array}{l}\lambda_{61} \\
\lambda_{71} \\
\lambda_{81} \\
\lambda_{91} \\
\lambda_{101}\end{array}$ & $\begin{array}{l}0.65 \\
0.67 \\
0.51 \\
0.58 \\
0.56\end{array}$ & $\begin{array}{l}(0.54) \\
(0.47) \\
(0.40) \\
(0.46) \\
(0.44)\end{array}$ & $\begin{array}{l}\delta_{6} \\
\delta_{7} \\
\delta_{8} \\
\delta_{9} \\
\delta_{10}\end{array}$ & $\begin{array}{l}0.29 \\
0.22 \\
0.16 \\
0.21 \\
0.20\end{array}$ \\
\hline$\xi_{2}$ Use & $\begin{array}{l}X_{11} \text { Creative with household items } \\
X_{12} \text { Experiment when using products } \\
X_{13} \text { Save parts for future uses } \\
X_{14} \text { Preferred assembling products } \\
X_{15} \text { My creations turn out well } \\
X_{16} \text { Enjoy computer programs not } \\
\text { yet needed }\end{array}$ & $\begin{array}{l}\lambda_{112} \\
\lambda_{122} \\
\lambda_{132} \\
\lambda_{142} \\
\lambda_{152} \\
\lambda_{162}\end{array}$ & $\begin{array}{l}0.57 \\
0.76 \\
0.57 \\
0.66 \\
0.50 \\
0.73\end{array}$ & $\begin{array}{l}(0.42) \\
(0.66) \\
(0.39) \\
(0.56) \\
(0.42) \\
(0.60)\end{array}$ & $\begin{array}{l}\delta_{11} \\
\delta_{12} \\
\delta_{13} \\
\delta_{14} \\
\delta_{15} \\
\delta_{16}\end{array}$ & $\begin{array}{l}0.18 \\
0.44 \\
0.15 \\
0.31 \\
0.17 \\
0.36\end{array}$ \\
\hline$\xi_{3}$ Adoptive & $\begin{array}{l}\mathrm{X}_{17} \text { First with new tech products } \\
\mathrm{X}_{18} \text { Buy hi-tech before friends do } \\
\mathrm{X}_{19} \text { First with 'new look' clothes } \\
\mathrm{X}_{20} \text { Help family with technology } \\
\text { shopping }\end{array}$ & $\begin{array}{l}\lambda_{173} \\
\lambda_{183} \\
\lambda_{193} \\
\lambda_{203}\end{array}$ & $\begin{array}{l}0.92 \\
0.89 \\
0.64 \\
1.27\end{array}$ & $\begin{array}{l}(0.74) \\
(0.76) \\
(0.50) \\
(0.96)\end{array}$ & $\begin{array}{l}\delta_{17} \\
\delta_{18} \\
\delta_{19} \\
\delta_{20}\end{array}$ & $\begin{array}{l}0.55 \\
0.57 \\
0.25 \\
0.92\end{array}$ \\
\hline \multicolumn{2}{|c|}{ Phi matrix estimate } & $\begin{array}{l}\phi_{21} \\
\phi_{23} \\
\phi_{13} \\
\phi_{21}\end{array}$ & & $\begin{array}{l}(0.86) \\
(0.56) \\
(0.51)\end{array}$ & & \\
\hline
\end{tabular}

Notes: Chi-square with 149 degrees of freedom 208.51 ( $p=0.00094)$; goodness-of-fit index = 0.94; adjusted goodness-of-fit index $=0.91$; root mean square residuals $=0.036$

three a priori factors. ${ }^{73}$ It represents three latent variables: use, vicarious and adoptive innovativeness, and their constituent components. Joreskog and Sorbom $^{74}$ suggest that measurement models be used to confirm (or disprove) the data fit indicated by exploratory procedures.

\section{RESULTS}

Confirmatory factor analysis was performed via the LISREL 8.3 program $^{75}$ in order to estimate model parameters and test the model. Goodness of fit was determined by the chi-square statistic, weighed against the degrees of freedom equivalent to the number of known relationships, minus unknown parameters. The results show a chi-square value of 208.51 with 149 degrees of freedom at the $p=0.00094$ level for a 1.41 chi-square/degree of freedom ratio. A ratio of 3.00 or less has been recommended as well within the range of an acceptable model fit. ${ }^{76}$ Regarding the fit indices, statistical conventions of GFI $\geq 0.80$ and RMSEA $\leq 0.07$ are often followed. ${ }^{77}$ The GFI for the model was 0.94 and the RMSEA was 0.036, each indicating that the model fit the data well. Other fit indices (AGFI $=0.91$, NFI $=0.88$, CFI $=0.96)$ gave similar indications. LISREL parameter estimations of the associations of the $\mathrm{x}$ variables to the $\mathrm{E}$ 
variables are shown in Table 2. The measurement model is illustrated in Figure 1. The loadings of the $\mathrm{x}$ variables on latent variables are indicated by the lambda coefficients. To create a reference point for the $\mathrm{E}$ variable, one $\mathrm{x}$ variable was randomly chosen and fixed at 1.0, leaving the others to be freely estimated. As is indicated by Table 2, the latent constructs were well delineated; all $\mathrm{x}$ variable loadings were significant, indicating that there are real differences in the latent constructs accessed by the three-dimensional innovativeness scale.

\section{DISCUSSION}

The purpose of this study was to re-examine and more fully understand the dimensionality of innovativeness. This was done in the context of adolescent consumers. A scale that measures a three-dimensional conceptualisation of innovativeness was developed. The prospect of a new scale was examined because of the acquisitive nature of existing innovativeness scales. The study is the first step toward creating a psychometrically valid scale that addresses the three subconstructs of innovativeness. The results suggest that to measure the gestalt of consumer innovativeness, it is necessary to include items accessing vicarious and use innovativeness, as well as the acquisitive (adoptive innovativeness) items that pervade the literature. Although there is a popular notion that many of today's adolescents are technological whiz kids, little empirical evidence exists about adolescent innovativeness. The results of this study suggest that extant scales may be insensitive to innovativeness in adolescents. The study establishes the importance of vicarious and use innovativeness as well as adoptive innovativeness. In doing so, it provides vital information for efforts aimed at identifying and penetrating younger consumer segments.

Consumer innovativeness begins with vicarious innovativeness or information acquisition about new products. Raju ${ }^{78}$ suggests that vicarious innovativeness or vicarious variety seeking is the assembling of product information to be used for future decision making. This construct has been empirically linked to exploratory purchase behaviour. ${ }^{79}$ Conceptually, it captures an important element of how innovativeness is manifested among younger consumers. ${ }^{80}$ To solve consumption problems, vicarious-innovative individuals mentally contextualise a consumption situation and determine the products that will solve it. Ten items from the new scale captured vicarious innovativeness. The vicariously-innovative individual likes to learn about new products and computer programs and is confident in their use even if $s /$ he does not possess them. S/he likes to discover new products and brands, try them out, think about how $\mathrm{s} /$ he would use different products and spend time imagining the products of the future. The vicarious-innovative individual is a window shopper who likes to contemplate consumption and partake in new activities.

The use-innovative consumer finds new uses for products already acquired; use innovativeness is creative product consumption behaviour. For a consumer to employ products in new uses or discover multiple product uses, creative ability, curiosity and risk tolerance are required. The higher the consumer creativity level, the more confident and competent the evaluation of new products, and consequently, the higher level of use innovativeness. The scale contains six items related to use innovation. The use-innovative individual is comfortable with risk, likes 


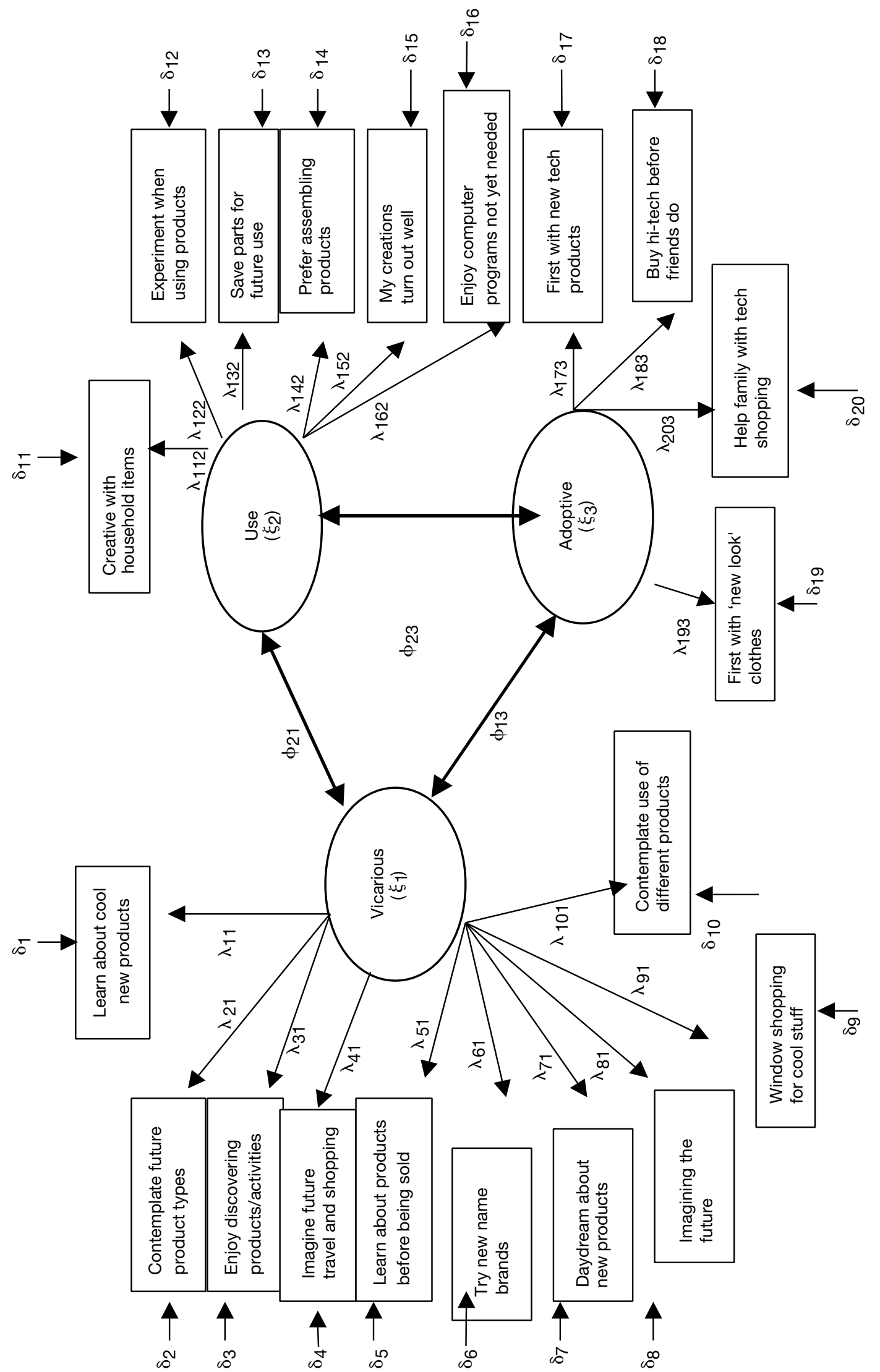


products that require assembly and has confidence in creating things, without assistance, from surplus parts saved from unused or broken products. S/he also enjoys experimenting with unfamiliar computer programs even if $\mathrm{s} /$ he has no application as yet for them.

The adoptive-innovative individual acquires novel products. Venkatraman ${ }^{81}$ suggests that individuals do this because the anticipated benefits outweigh the perceived risks. Ram and Jung ${ }^{82}$ suggest individuals do this because they have higher product involvement. The adoptive-innovativeness scale of this study consists of four items. It shares similarities with extant innovativeness scales. Characteristics of the adoptive-innovative individual include being the first who adopt and buy high-tech products like cell phones and high fashion clothes before friends do and helping family with high-tech product purchases.

\section{LIMITATIONS AND FUTURE RESEARCH}

This study argues that there is reason to believe that adolescents provide a useful subject context within which to develop a scale that more adequately measures the concept of innovativeness, adding considerations of use innovativeness and vicarious innovativeness to the pre-existing adoptive-innovativeness dominated measurement scales. To further assess the usefulness of this dimensional conceptualisation of innovativeness, however, clustering techniques could be utilised to determine whether segments with varying styles of innovativeness exist. The scale should also be tested in the context of other subject pools. Examination of three-dimensional innovativeness profiles of different age groups, for instance, should be examined and compared.
Petrosky ${ }^{83}$ points out that a comparison between men and women may also be of value.

Another avenue of inquiry would be to use the three-dimensional innovativeness scale in conjunction with other scales related to concepts such as search strategies or risk preferences to determine if these concepts are related to innovativeness types as the literature suggests. By re-examining innovativeness, advances may accrue in the study of brand loyalty, decision making, preference and communication. ${ }^{84}$

Future research should also examine the criterion validity of the scale by determining its ability to predict innovative behaviour. This could be very useful if done in various product markets to more properly assess the scale's commercial usefulness. An assessment of the measurement scale's ability to predict innovativeness toward technologyoriented products would be useful for targeting the most receptive segments for the earliest stages of product introduction. Assessing the measurement scale's ability to predict innovativeness toward relatively more prosaic products may provide a more demanding test of the instrument's robustness.

For now, the results of this study should not be interpreted too broadly. The study has produced a scale that appears to have good content, construct and face validity, with reliabilities within the desirable range for the social sciences. The one city sample of adolescent subjects needs to be further tested, however. Multitrait, multimethod techniques should be employed to further validate the scale. Future research could also employ larger samples to enhance the generalisability of the scale. With its empirical support for the threedimensional conceptualisation of innovativeness, this study augments the foundation of knowledge that has been 
laid by past innovativeness research and represents an important new direction for measurement and targeting of innovative segments.

\section{References}

1 Venkatesh, A. and Nicosia, F. (1997) 'New technologies for the home-development of a theoretical model of household adoption and use', Paper presented at the Advances in Consumer Research Conference.

2 Hirschman, E. C. (1980) 'Innovativeness, novelty seeking and consumer creativity', Journal of Consumer Research, Vol. 7, December, pp. 283-295.

3 Shim, S. (1996) 'Adolescent consumer decision-making styles: The consumer socialization perspective', Psychology and Marketing, Vol. 13, No. 6, pp. 547-569.

4 Corfman, K. (1997) 'Children as decision makers', paper presented at the Advances in Consumer Research Conference.

5 Subrahmanyam, K., Draut, R. E., Greenfield, P. M. and Gross, E. F. (2000) ' The impact of home computer use on children's activities and development', Future of Children, Vol. 10, No. 2, pp. 123-144.

6 Midgley, D. F. and Dowling, G. R. (1978) 'Innovativeness: The concept and its measurement', Journal of Consumer Research, Vol. 4, pp. 229-242.

7 Mowen, J. C. (2000) 'The 3M Model of Motivation and Personality: Theory and empirical applications to consumer behavior', Kluwer Academic Press, New York.

8 Venkatraman, M. P. (1991) 'The impact of innovativeness and innovation type on adoption', Journal of Retailing, Vol. 67, No. 1, pp. 51-67.

9 Rogers, E. M. (1983) 'Diffusion of innovations', The Free Press, New York.

10 Hirschman (1980) op. cit.

11 Price, L. L. and Ridgway, N. M. (1983) 'Development of a scale to measure use innovativeness', Advances in Consumer Research, Vol. 10, pp. 679-684.

12 Hirschman (1980) op. cit.

13 Bristor, J. M. and Fischer, E. (1993) 'Feminist thought: Implications for consumer research', Journal of Consumer Research, Vol. 19, March, pp. 518-536.

14 Rogers (1983) op. cit.

15 Venkatesh and Nicosia (1997) op. cit.

16 Petrosky, A. R. (1995) 'Gender and use innovation: An inquiry into the socialization of innovative behavior', paper presented at the American Marketing Association Conference.

17 Ibid.

18 Venkatraman (1991) op. cit.

19 Hirschman (1980) op. cit.

20 Rogers (1983) op. cit.

21 Midgley and Dowling (1978) op. cit.

22 Mowen (2000) op. cit.
23 Hirschman (1980) op. cit.

24 Price and Ridgway (1993) op. cit.

25 Midgley and Dowling (1978) op. cit.

26 Hirschman (1980) op. cit.

27 Subramanian, S. and Mittelstaedt, R. A. (1991)

'Conceptualizing innovativeness as a consumer trait: Consequences and alternatives', American Marketing Association Educators' Proceedings, Vol. 2, pp. 352-360.

28 Venkatraman (1991) op. cit.

29 Venkatraman, M. P. and Price, L. L. (1990)

'Differentiating between cognitive and sensory innovativeness', Journal of Business Research, Vol. 20, pp. 293-315.

30 Rogers (1983) op. cit.

31 Lowrey, T. M. (1991) 'The use of diffusion theory in marketing: A qualitative approach to innovative consumer behavior', paper presented at the Advances in Consumer Research Conference.

32 Gatignon, H. and Robertson, T. S. (1985) 'A propositional inventory for new diffusion research', Journal of Consumer Research, Vol. 11, March, pp. 849-867.

33 Robertson, T. S. (1967) 'The process of innovation and the diffusion of innovation', Journal of Marketing, Vol. 31, January, pp. 14-19.

34 Dickerson, M. D. and Gentry, J. (1983) 'Characteristics of adopters and non-adopters of home computers', Journal of Consumer Research, Vol. 10, September, pp. 225-235.

35 Korgaonkar, P. K. and Moschis, G. P. (1987) 'Consumer adoption of videotex services', Journal of Direct Marketing, Vol. 1, No. 4, pp. 63-71.

36 Hirschman, E. C. (1981) 'Innovativeness, novelty seeking, and consumer creativity', Journal of Consumer Research, Vol. 7, December, pp. 283-295.

37 Solomon, M. R. (1996) 'Consumer behavior: Buying, having, and being', Prentice-Hall, USA.

38 Rogers (1983) op. cit.

39 Kotler, P. (2003) 'Marketing management', 11th edn, Prentice Hall, Upper Saddle River, NJ.

40 Rogers (1983) op. cit.

41 Ibid.

42 Hirschman (1980) op. cit.

43 Rogers and Shoemaker (1971) op. cit., p. 27.

44 Midgley and Dowling (1978) op. cit.

45 Subramanian and Mittelstaedt (1991) op. cit.

46 Petrosky (1995) op. cit.

47 Ram, S. and Jung, H-S. (1994) 'Innovativeness in product usage: A comparison of early adopters and early majority', Psychology and Marketing, Vol. 11, No. 1, pp. 57-67.

48 Hirschman (1980) op. cit.

49 Price, L. and Ridgway, N. (1982) 'Use innovativeness, vicarious exploration and purchase exploration: Three facets of consumer varied behavior', paper presented at the Educators' Conference.

50 Hirschman (1980) op. cit.

51 Raju, P. S. (1980) 'Optimum stimulation level: Its relationship to personality', Journal of Consumer Research, Vol. 7, December, pp. 272-282.

52 Hirschman (1980) op. cit. 
53 Freud, S. (1923) 'The ego and the id', (J. Riviere, trans.), (1960 edn), W W Norton and Co., New York.

54 Erikson, E. H. (1963) 'Childhood and society', (2nd edn), W W Norton and Co., New York.

55 Ibid.

56 Schachtel, E. G. (1959) 'Metamorphosis', Basic Books, New York

57 Crockett, L. J. and Petersen, A. C. (1993)

'Adolescent development: Health risks and opportunities for health promotion', in Millstein, S. G., Petersen, A. C. and Nightingale, E. O. (eds) 'Promoting the health of adolescents: New directions for the twenty-first century', Oxford University Press, New York, pp. 3-37.

58 Bandura, A. (1986) 'Social foundations of thought and action: A social cognitive theory', Prentice Hall, Englewood Cliffs, NJ.

59 Csikszentmihalyi, M. and Larson, R. (1984) 'Being adolescent', Basic Books, New York.

60 Timmer, S., Eccles, J. and O'Brien, I. (1985) 'Time, goods, and well being', University of Michigan, Institute for Social Research, Ann Arbor. 61 Bandura (1986) op. cit.

62 Kynigos, C., Gyftodimos, G. and Georgiadis, P. (1993) 'Empowering a society of future users of information technology: A longitudinal study of an application in early education', European Journal of Information Systems, Vol. 2, No. 2, pp. 139-148.

63 Breakwell, G. M. and Fife-Schaw, C. (1987) 'Young people's attitudes toward new technology: Source and structure', in Lewko, J. H. (ed.) 'How children and adolescents view the world of work', Vol. 35, pp. 51-67, Jossey-Bass Inc., San Francisco.

64 Sudman, S. and Bradburn, N. M. (1986) 'Asking questions', Jossey-Bass Publishers, San Francisco.

65 Price and Ridgway (1993) op. cit.

66 Peterson, R. A. (1982) 'Marketing research', Business Publications Inc., Plano, Texas.
67 Nunnally, J. C. and Bernstein, I. H. (1994) 'Psychometric Theory', third edn, McGraw-Hill, Inc., New York.

68 Malhotra, N. K. (1981) 'A scale to measure self-concepts, person concepts and product concepts', Journal of Marketing Research, Vol. 18, November, pp. 456-464.

69 Nunnally and Bernstein (1994) op. cit.

70 Churchill, G. A. (1979) 'A paradigm for developing better measures of marketing constructs', Journal of Marketing Research, Vol. 16, February, pp. 64-73.

71 Goldsmith, R. E. and Hofacker, C. A. (1991) 'Measuring consumer innovativeness', Journal of the Academy of Marketing Sciences, Vol. 19, No. 3, pp. 209-221.

72 Nunnally and Bernstein (1994) op. cit.

73 Bentler, P. M. (1995) 'EQS for Windows - User's Guide', Multivariate Software, Inc., Encino, CA.

74 Joreskog, K. and Sorbom, D. (1989) 'LISREL 7: A Guide to the Program and Applications', SPSS Inc., Chicago, IL.

75 Ibid.

76 Carmines, E. G. and McIver, P. P. (1981) 'Analyzing models with unobserved variables: Analysis of covariance structures', in Bohrnstedt, G. W. and Borgatta, E. F. (eds) 'Social measurement: Current issues', Sage Publications, Beverly Hills, CA.

77 Browne, M. W. and Cudeck, R. (1993) 'Alternative ways of assessing model fit', in Bollen, K. A. and Scott Long, J. (eds) 'Testing structural equation models', Sage Publications, Newbury Park, CA, pp. 136-162.

78 Raju (1980) op. cit.

79 Price and Ridgway (1982) op. cit.

80 Bandura (1986) op. cit.

81 Venkatraman (1991) op. cit.

82 Ram and Jung (1994) op. cit.

83 Petrosky (1995) op. cit.

84 Hirschman (1980) op. cit. 